\title{
PENGEMBANGAN PROFESIONALISME GURU SMA, MA, DAN SMK MUHAMMADIYAH SUKOHARJO JAWA TENGAH
}

\author{
Bambang Sumardjoko dan Agus Prasetyo \\ Program Studi PPKn FKIP UMS \\ Jl. A.Yani, Tromol Pos 1, Pabelan, Kartasura, Surakarta 57102 \\ (email: bs131@ums.ac.id)
}

\begin{abstract}
Abtsract: The purposes of the research is to find the sustainable model of teacher professional development based on collaborative constructivist to improve soft skills in the writing scientific articles. The study designed for research development. Data collection techniques used are: observation, interviews, documentation, focus group discussion, and questionnaires. Data analysis techniques are qualitative and quantitative analysis. The results of this research are: 1) Muhammadiyah high school teachers in Sukoharjo who are certified educators have been doing a series of activities to develop competence, both independent workshops, seminars, purchase of textbooks latest, following the activities MGMPs and collective activity visities such as discussing fellow of teachers; 2) The ability to write scientific papers, the certified teachers have not fully understood the concept of scientific work, 3) to meet the needs of continuous professional development teachers are still encountering many obstacles , such as the constraints of time , money, age , infrastructure , motivation, policy management, and Internet network access; 4) the initial design model of continuous professional development of teachers constructivist -based collaborative to improve the soft skills of teachers in the writing of scientific articles is integrated . The model is based on the needs of teachers in preparing scientific articles and constructively developed by teachers themselves, while external teams provide reinforcement and assistance in the preparation of scientific articles .
\end{abstract}

Keywords: teacher professional development model, scientific articles

Abstrak: Tujuan utama penelitian adalah menemukan model pengembangan profesi
guru berkelanjutan berbasis konstruktivis kolaboratif untuk meningkatkan soft skills-
transferable skills dalam penulisan artikel ilmiah. Desain penelitian menerapkan
penelitian pengembangan. Teknik pengumpulan data menggunakan observasi,
wawancara, dokumentasi, FGD, dan angket. Analisis data menggunakan analisis
kualitatif dan kuantitatif. Hasil penelitian menunjukkan yang pertama, guru-guru
SMA/MA/SMK Muhammadiyah di Sukoharjo yang bersertifikasi pendidik selama
ini telah melakukan serangkaian kegiatan untuk mengembangkan kompetensinya,
baik secara mandiri dengan mengikuti workshop, seminar, membeli buku teks
pelajaran terbaru, mengikuti kegiatan MGMP maupun bersama-sama dengan cara
berdiskusi sesama rekan guru bidang studi. Kedua, dalam kemampuan menulis karya
ilmiah, guru-guru bersertifikasi pendidik belum sepenuhnya memiliki pemahaman
konsep karya ilmiah. Ketiga, untuk memenuhi kebutuhan pengembangan keprofesian
guru berkelanjutan masih menemui kendala, seperti kendala waktu, dana, usia,
sarana prasarana, motivasi, kebijakan pimpinan, dan akses jaringan internet.
Keempat, desain awal model pengembangan keprofesian guru berkelanjutan berbasis
konstruktivis-kolaboratif untuk meningkatkan soft skills guru dalam penulisan artikel 
ilmiah bersifat terpadu. Model didasarkan pada kebutuhan guru dalam menyusun artikel ilmiah dan dikembangkan secara konstruktif oleh guru sendiri, sementara tim eksternal memberikan penguatan dan pendampingan dalam penyusunan artikel ilmiah.

Kata Kunci: model keprofesian, pengembangan keprofesian, dan karya ilmiah

\section{Pendahuluan}

Sumber daya manusia (SDM) yang berkualitas menjadi kebutuhan bagi bangsa Indonesia agar mampu menjawab berbagai tantangan baik lokal, nasional, maupun internasional. Modernitas saat ini juga memerlukan SDM yang berkualitas, bahkan menjadi faktor determinan bagi kemajuan sebuah bangsa. SDM berkualitas disiapkan oleh para guru profesional dan institusi pendidikan yang bermututinggi. Hal ini selaras dengan penegasan Sahlberg (2007), yang menyatakan bahwa ekonomi modern dengan pasar tenaga kerja membutuhkan orang-orang dengan keterampilan dan pengetahuan yang tidak dapat dikembangkan di sekolah yang berkualitas rendah. Selanjutnya, menurut Ayhan (2011) juga bahwa hal yang sangat penting dalam perekonomian negara saat ini adalah menghasilkan tenaga kerja yang berkualitas tinggi.

Guru merupakan tenaga pengajar dalam institusi pendidikan. Guru adalah pendidik profesional dengan tugas utama mendidik, mengajar, membimbing, mengarahkan, melatih, menilai, dan mengevaluasi peserta didik pada pendidikan anak usia dini jalur pendidikan formal, pendidikan dasar dan pendidikan menengah. Kedudukan guru sebagai tenaga profesional berfungsi untuk meningkatkan martabat dan peran guru sebagai agen pembelajaran dan untuk meningkatkan mutu pendidikan nasional (UU No 14 Tahun 2005).

Guru sebagai pengajar dituntut memiliki kompetensi atau kemampuan paedagogi sehingga mampu mentransformasikan ilmu pengetahuan kepada peserta didiknya. Dalam proses pendidikan guru tidak hanya menjalankan fungsi alih ilmu pengetahuan (transfer of knowledge) tetapi juga menjalankan fungsi menanamkan nilai (value) serta membangun karakter (character building) peserta didik secara berkelanjutan dan berkesinambungan. Peran guru menjadi sangat strategis dalam menyiapkan SDM yang berkualitas. Karena itu peningkatan profesionalisme guru secara terus-menerus perlu dilakukan.

Pengembangan profesionalisasi guru dilakukan berdasarkan kebutuhan institusi, kelompok guru, dan guru sendiri. Hal ini sejalan dengan pendapat Danim (dalam Syaefudin Sa'ud, 2009) bahwa pengembangan guru dimaksudkan untuk merangsang, memelihara, dan meningkatkan kualitas staf dalam memecahkan masalahmasalah keorganisasian. Meski dikatakan bahwa pengembangan guru berdasarkan kebutuhan institusi adalah penting namun hal yang lebih penting dalam pengembangan profesi guru adalah berdasarkan kebutuhan individu guru sendiri untuk menjalani proses profesionalisasi. Hal ini penting karena substansi kajian dan konteks pembelajaran selalu berkembang dan berubah menurut dimensi ruang dan waktu sehingga guru dituntut untuk selalu meningkatkan kompetensinya dengan cara pengembangan keprofesian berkelanjutan (PKB).

Berbicara tentang pengembangan profesi guru berkelanjutan diperoleh data bahwa banyak guru termasuk di dalamnya guru berstatus Pegawai Negeri Sipil dalam pengembangan keprofesian terhalang oleh keharusan pembuatan karya ilmiah. Padahal kemampuan menulis karya ilmiah itu penting bagi guru (Anah Suhaenah, Kompas, 22 April 2014) karena dengan menulis karya ilmiah dapat berguna sebagai sarana guru dalam 
merefleksikan berbagai pengalamannya. Di Propinsi Jawa Tengah misalnya, hampir 60\% guru PNS yang telah mencapai golongan ruang IVa tidak dapat naik pangkat setingkat lebih tinggi karena terkendala masalah penulisan karya ilmiah. Data menunjukkan bahwa Guru Sekolah Menengah yang telah menduduki pangkat golongan IVa mencapai $50,88 \%$ sedangkan guru yang mampu naik pangkat ke IVb dan seterusnya hanya sebesar 0,5\%. (Eris Yunianto, 2007). Penelitian Sumardjoko (2013) tentang Model Penguatan Guru Bersertifikasi melalui Pemaknaan Profesionalisme, pada Guru-guru SMA Negeri di Sukoharjo Jawa Tengah menunjukkan bahwa faktor dominan penyebab kurang berhasilnya guru dalam meningkatkan profesionalisme adalah kurangnya kemampuan guru dalam melakukan penelitian tindakan kelas dan menulis karya ilmiah.

Kemudian, berdasarkan observasi awal di sekolah Muhammadiyah (SMA/ MA/SMK) Sukoharjo, ditemukan bahwa dalam pengembangan keprofesian guru berkelanjutan cenderung stagnan atau jalan di tempat dan belum tampak adanya programprogram pengembangan keprofesian guru yang tersusun secara jelas dan sistematis. Karena itu berdasarkan fenomena di atas maka dipandang perlu untuk merumuskan sebuah pengembangan model keprofesionalan guru berkelanjutan berbasis konstruktiviskolaboratif untuk meningkatkan soft skillstransferable skills guru dalam penulisan artikel ilmiah.

Soft skills merupakan kompetensi yang sulit didefinisikan karena sangat subjektif. Soft skill merujuk pada kompetensi interpersonal atau kepribadian. Terdapat bermacammacam kompetensi interpersonal yang sudah teridentifikasi. Berdasarkan publikasi Career Opportunities News disebutkan bahwa soft skills meliputi keterampilan yang positif untuk mendukung kepribadian. Soft skills dapat berupa: motivasi, menghormati orang lain, bekerja dalam tim, disiplin diri, percaya diri, penyesuaian terhadap norma-norma yang berlaku umum, dan kecakapan berbahasa atau berkomunikasi baik lisan maupun tertulis. Guru yang mempunyai soft skill positif diharapkan dapat menguasai komunikasi secara lisan dan tertulis serta mempunyai motivasi kerja yang tinggi sehingga mampu bekerja secara intensif di bawah tekanan target produk dan batas waktu (deadline).

Soft skill hanya dapat dinterpretasikan secara kualitatif melalui observasi perilaku manusia. Kompetensi teknik atau hard skill lebih mudah untuk diidentifikasi sebab lebih objektif dan dapat diukur secara kuantitatif. Data hasil pengukuran soft skill berupa dampak yang positif atau negatif dalam interaksi manusia. Soft skill dibutuhkan terutama dalam menghadapi stressor (tekanan yang dapat menyebabkan stres). Seseorang yang mempunyai soft skill bagus adalah orang yang dapat berdaya di kemudian hari karena dapat mengelola kehidupan pribadi, baik secara internal ke dalam dirinya maupun secara eksternal dalam menjalin hubungan dengan orang lain.

Besarnya pengaruh kepribadian dalam kehidupan kerja membuat banyak penelitian yang mengidentifikasi kompetensi interpersonal yang diperlukan oleh seorang pekerja. Marquardt \& Engel (1993) menghubungkan kompetensi dosen dengan kebutuhan global pasar kerja. Kompetensi yang membuat dosen efektif tidak menjamin efektivitas dalam tatanan budaya. Marquardt \& Engel mengidentifikasi 16 kompetensi yang disusun berdasarkan wilayah sikap, (attitude) keterampilan (skills) dan pengetahuan (knowledge) yang dipercaya mempunyai konstribusi tinggi untuk meraih sukses dalam tatanan lintas budaya. Kompetensi sikap yang disarankan adalah (1) menghargai nilai-nilai dan praktek budaya lain, (2) sabar dan toleran, (3) komitmen terhadap prinsip-prinsip SDM, (4) banyak inisiatif, tekun, dan (5) mempunyai rasa humor. McLagan (1989) mengidentifikasi 25 kompetensi yang harus dimiliki guru dalam 'Models for HRD Practice'. Kompetensi tersebut kemudian diklasifikasikan menjadi 
4 kelompok, yaitu kompetensi teknik, bisnis, interpersonal, dan intelektual. Soft skill menjadi bagian dari kompetensi HRD profesional yang termuat dalam kompetensi interpersonal. Leach (1999) menguji kembali model yang dikembangkan oleh McLagan dan menemukan 23 kompetensi yang masih relevan untuk menyiapkan tenaga guru yang profesional.

Soft skill dapat membangun kepribadian guru yang mantap. Berdasarkan hasil penelitian pada dosen yang efektif ditemukan gejala umum bahwa dosen yang disukai oleh mahasiswanya adalah dosen yang mempunyai kepribadian positif. Hasil penelitian Gordon (1999) menemukan delapan dari 18 pernyataan kompetensi mengajar efektif dan mempunyai hubungan signifikan dan positif adalah tipe kepribadian. Data mengindikasikan bahwa $42.25 \%$ variasi kompetensi dapat diprediksi dari tipe kepribadian. Dimensi tipe kepribadian dosen yang mempunyai skor tinggi dalam efektivitas mengajar adalah apakah kehadiran dosen diperlukan atau diinginkan, dan apakah mereka bekerja dengan sekuat tenaga untuk menyelesaikan pekerjaan secara penuh dan tepat waktu. Dosen yang menghargai prosedur yang ditetapkan dan otoritas, percaya bahwa mereka akan tetap dapat bertahan sebab mereka sudah menjalankan fungsinya dengan baik. Dosen yang seperti ini pada umumnya lebih mempunyai perasaan dan intuisi. Dosen yang mendapat skor rendah atau kurang efektif menurut Myers and McCaulley (1985), yaitu apabila dosen tidak menemukan tempat yang dapat digunakan untuk menyalurkan kecerdasan dan apresiasinya atau memperoleh tempat yang dapat memberi sumbangan tinggi untuk hidupnya, merasa frustasi dan dingin, dogmatis, ragu-ragu, merasa berdosa, menjadi terganggu, merasa ahli dan mengetahui semua, merasa lebih berkuasa dari yang lain, dan menolak untuk mendengarkan.

Berdasarkan deskripsi latar belakang dan teori di atas maka tujuan penulisan model pengembangankeprofesianguruberkelanjutan berbasis konstruktivis kolaboratif untuk meningkatkan soft skills-transferable skills guru dalam penulisan karya ilmiah ini adalah sebagai berikut. (1) Mendeskripsikan hasil pemetaan model pengembangan keprofesian guru berkelanjutan yang tengah berlangsung, (2) Mendeskripsikan hasil pemetaan kemampuan guru dalam menulis karya ilmiah, (3) Mendeskripsikan hasil analisis bentuk-bentuk kebutuhan guru pada pengembangan keprofesian berkelanjutan, dan (4) Menunjukkan draft model pengembangan profesi guru berkelanjutan bagi guru-guru bersertifikasi pendidik di perguruan Muhammadiyah Sukoharjo.

\section{Metode}

Penelitian pengembangan ini dilakukan di Kabupaten Sukoharjo, Propinsi Jawa Tengah. Sumber data meliputi informan, tempat/ peristiwa, dan dokumen yang didasarkan atas snowball sampling dan purposive sampling. Teknisnya, peneliti memulai dengan teknik cuplikan snowball, artinya untuk memperoleh cuplikan yang bersifat purposive terlebih dahulu peneliti melakukan penjelajahan sampai dengan ditemukannya cuplikan yang benar-benar diinginkan. Teknik snowball dilakukan atas dasar bahwa ketika peneliti memasuki lokasi penelitian tidak memiliki peta sumber data yang secara akurat telah diketahui sebelumnya.

Penelitian ini merupakan penelitian intensif yang bersifat pengembangan (research and development), yaitu suatu penelitian yang dimulai dengan studi pendahuluan kemudian ditindaklanjuti dengan kegiatan pengembangan melalui proses studi lapangan, pengembangan desain model, ujicoba desain model, dan validasi model.

\section{Hasil dan Pembahasan}

\section{Deskripsi Data Guru SMA/MA/SMK Muhammadiyah Sukoharjo}

Amal Usaha Muhammadiyah (AUM) bidang pendidikan di Daerah Muhammadiyah Sukoharjo tergolong 
banyak. Lembaga pendidikan yang berupa sekolah menengah atas, yaitu SMA, MA, dan SMK Muhammadiyah sebanyak 11 sekolah. Berdasarkan pencatatan tanggal 27 Juni 2015, ditemukan data jumlah total guru di 11 (sebelas) sekolah di atas sejumlah 346 orang.

Dari sejumlah 346 guru tersebut maka yang sudah mengikuti program sertifikasi pendidik sejumlah 119 orang atau sebesar $34,39 \%$ dan yang belum mengikuti program sertifikasi pendidik sejumlah 227 orang atau $65,61 \%$. Ini menunjukkan bahwa guru yang belum mengikuti program sertifikasi lebih banyak dari pada yang sudah mengikuti program sertifikasi. Namun demikian, meski baru sebesar 34,39\% yang mengikuti program sertifikasi pendidik, sebagai sebuah perguruan swasta maka jumlah di atas dapat dikatakan baik karena telah berada di atas angka $25 \%$.

Dari 119 guru yang telah memperoleh sertifikat pendidik, berdasarkan status kepegawaiannya terbagi menjadi tiga kategori, yakni berstatus Pegawai Negeri Sipil, Guru Tetap Yayasan, dan Guru Tidak Tetap. Guru bersertifikasi pendidik yang berstatus PNS sejumlah 20 orang atau $16.81 \%$, berstatus GTY sejumlah 72 orang atau $60.50 \%$, dan berstatus GTT sejumlah 27 orang guru atau $22.69 \%$. Data menurut status kepegawaian ini cukup menarik karena guru berstatus non PNS banyak yang memperoleh sertifikasi pendidik, yakni sebesar 83,19\% dibandingkan dengan guru berstatus PNS.

Dari sejumlah 119 orang guru SMA/ MA/SMK Muhammadiyah Sukoharjo yang telah bersertifikasi pendidik menurut tingkat pendidikannya dapat dibagi menjadi dua kategori, yakni berpendidikan akhir magister (S.2) dan pendidikan akhir sarjana (S.1). Guru bersertifikasi pendidik yang bergelar S.2 sejumlah 10 orang atau $08,40 \%$ dan bergelar S.1 sejumlah 109 orang atau 91,60\%. Data menurut tingkat pendidikan ini menunjukkan bahwa masih sedikit yang memiliki gelar S.2 yakni $08,40 \%$ sehingga perlu peningkatan yang bergelar S1 untuk mengikuti program pendidikan jenjang di atasnya.

Kemudian, menurut jenis kelamin dari sejumlah 119 guru SMA/MA/SMK Muhammadiyah Sukoharjo yang telah bersertifikasi pendidik terbagi menjadi pria sejumlah 81 orang atau $68,07 \%$ dan wanita 38 orang atau $31,93 \%$. Data menurut jenis kelamin ini menunjukkan bahwa guru pria masih menjadi mayoritas yang memperoleh sertifikasi pendidik daripada guru wanita. Dalam bentuk histogram data profil guru bersertifikasi pendidik di atas digambarkan sebagai berikut.

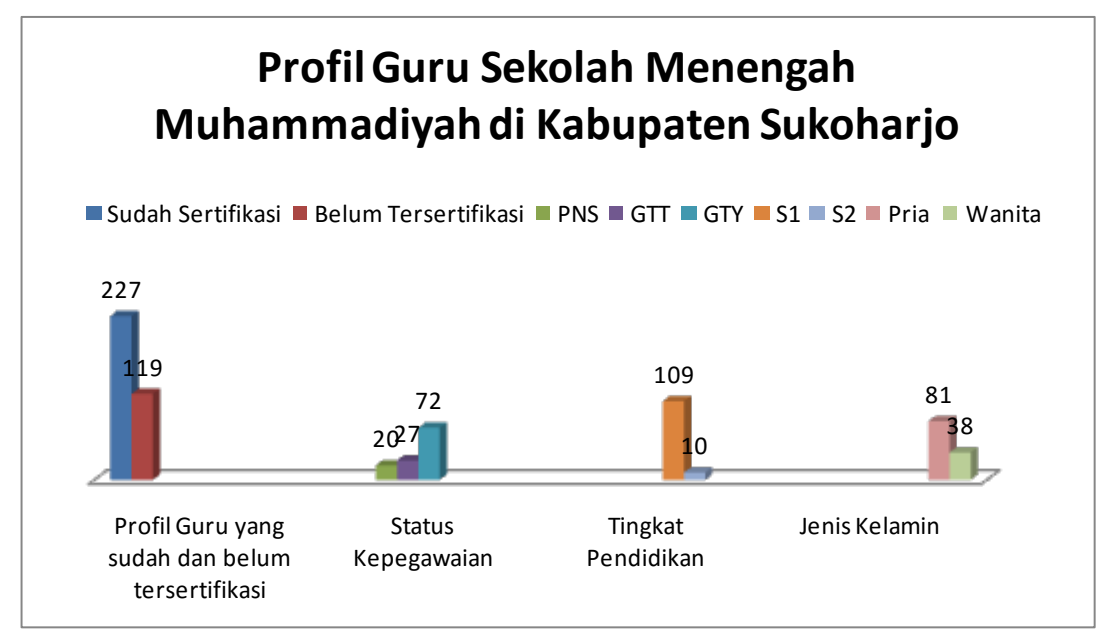

Histogram 1 Profil Guru SMA/MA/SMK Muhammadiyah Sukoharjo 
2. Deskripsi Pengembangan Keprofesian Guru

\section{a. Dari Perspektif Guru}

Berdasarkan studi pendahuluan bahwa pada dasarnya segala bentuk pengembangan diri guru bersertifikasi pendidik sudah dilakukan meski hasilnya belum maksimal. Guru telah berusaha melakukan berbagai pengembangan diri untuk memenuhi dan meningkatkan kompetensi paedagogik, keprofesionalan, sosial, dan kepribadian.

Bukti-bukti kegiatan pengembangan diri guru itu ditunjukkan dari hasil wawancara kepada beberapa informan. MenurutDrs. BS, M.Pd selaku guru PPKn di SMK Muhammadiyah 1 Sukoharjo (wawancara 5 Juni 2015) mengatakan bahwa "Selama ini saya banyak membaca buku, mengikuti workshop, dan outbond. Jika itu dilakukan semua, saya rasa cukup untuk meningkatkan kompetensi". Hasil informasi ini dikuatkan oleh guru sejarah, yakni Bapak SS,S.Pd, yang mengatakan: "Saya selain baca buku, juga sering melihat di internet. Karena peristiwa sejarah lebih mudah jika mencari di internet. Datang di seminar atau workshop juga pernah. Itu bisa mendukung kompetensi saya sebagai guru Sejarah".

Informasi yang didapatkan dari kedua nara sumber di atas rupanya tidak jauh berbeda dengan yang dilakukan Drs. H.Sm, M.Si guru bersertifikasi pengampu kewirausahaan di SMK Muhammadiyah 1 Sukoharjo. Sebagai guru PPKn, Bapak ES, S.Pd (tanggal 8 Juni 2015), telah mengembangkan kompetensi, ikut kegiatan-kegiatan MGMP. Lantas juga beli laptop untuk internetan, karena menurutnya sangat bagus untuk mencari informasi yang terbaru mengenai isu-isu kewarganegaraan. Keterangan ES ini diperkuat oleh Drs. W yang mengampu bidang studi Penjaskes dan Sgn, S.Pd,.M.Hum, pengampu mata pelajaran Bahasa Indonesia dan berstatus PNS.

Berdasarkan hasil wawancara di atas diperoleh gambaran bahwa guruguru yang bersertifikasi pendidik selama ini telah melakukan beberapa kegiatan untuk mengembangkan kompetensi setelah bersertifikasi. Kegiatan yang dilakukan berupa mengikuti workshop, seminar, membeli buku teks pelajaran terbaru, mengikuti kegiatan MGMP, serta berdiskusi dengan rekan guru bidang studi.

Pengumpulan data kepada beberapa guru SMA/MA/SMK Muhammadiyah di Sukoharjo memberikan gambaran terkait kegiatan yang dilakukan selama ini dalam hal pengembangan keprofesionalan guru berkelanjutan. Berbagai usaha dan kegiatan guru dalam meningkatkan profesionalisme secara berkelanjutan tersebut dapat ditunjukkan dalam gambar histogram sebagai berikut. 


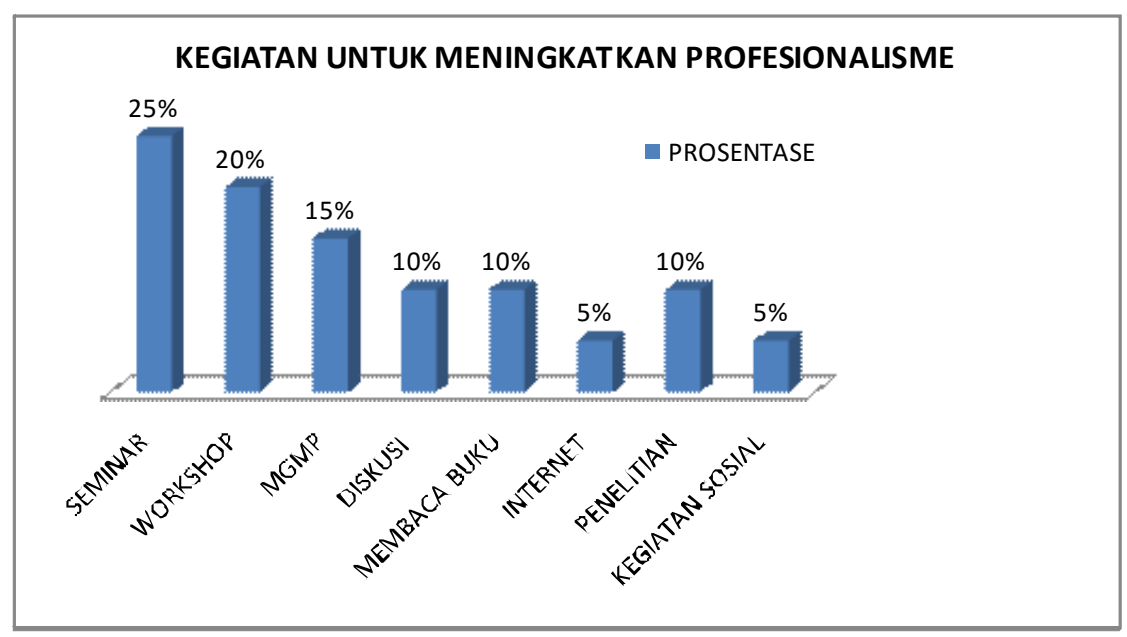

Histogram 2. Kegiatan Guru Meningkatkan Profesionalisme

\section{b. Dari Perspektif Kepala Sekolah}

Kepala sekolah sebagai pimpinan turut bertanggung jawab dalam pengembangan profesionalisme guru di sekolah. Berbagai cara dilakukan kepala sekolah untuk mendukung guru bersertifikasi agar memiliki kompetensi yang lebih baik. Bapak Drs. HM, MM. sebagai kepala sekolah SMK 2 Muhammadiyah Sukoharjo menyatakan mendukung setiap aktivitas guru untuk mengembangkan kompetensi. Berdasarkan hasil wawancara pada tanggal 8 Juni 2015, beliau mengatakan: "Apabila ada undangan seminar atau worskhop, kami akan mengirimkan guru. Untuk dana dibantu dari sekolah. Guru diberikan surat perjalanan dinas, lantas di cap pada panitia di seminar/workshop. Selanjutnya bukti itu diserahkan ke sekolah. Kegiatan MGMP juga didukung, terutama penyediaan tempat jika dibutuhkan. Terkait jam mengajar, kami sesuaikan dengan kebutuhan guru khususnya yang bersertifikasi agar sesuai kebutuhan jam mengajarnya. Masih banyak lagi kegiatan lain untuk mengembangkan kompetensi guru".

Informasi dari Drs. HM, MM, kemudian dikroscek dengan Drs. Mdj sebagai kepala sekolah di SMA Muhammadiyah 1 Sukoharjo ternyata pendapatnya sama. Menurutnya jika pihak sekolah mendukung penuh terkait pengembangan kompetensi guru, meski terkadang menemui kendala. Termasuk Bapak Skn, M.Pd sebagai kepala sekolah SMK Muhammadiyah Watukelir dan Kepala sekolah SMA Muhammadiyah Pontren Imam Syuhada yang selalu mendukung setiap aktivitas guru dalam pengembangan kompetensi.

Pengumpulan data yang telah dilakukan dengan beberapa kepala sekolah SMA/MA/SMK Muhammadiyah di Sukoharjo memberikan gambaran terkait kegiatan yang dilakukan selama ini dalam hal pengembangan kompetensi guru bersertifikasi. Berdasarkan hasil penelitian diperoleh gambaran bahwa kepala sekolah ternyata selama ini telah berusaha mendukung guru bersertifikasi untuk melakukan berbagai kegiatan guna meningkatkan kompetensi paedagogik, profesional, kepribadian, dan sosial. Dukungan yang dilakukan antara lain: (1) Memberikan dukungan kepada guru apabila ingin mengikuti seminar. (2) Memberikan dukungan kepada guru apabila ingin mengikuti workshop. (3) Memfasilitasi kegiatan diskusi dengan rekan bidang studi di sekolah masingmasing. (4) Memberikan terhadap kegiatan MGMP. (5) Memotivasi guru bersertifikasi yang sudah berusia tua, agar tetap produktif. (6) Mendukung 
guru dalam menyelenggarakan kegiatan sosial pada acara hari besar keagamaan.

(7) Memberikan pengawasan terhadap aktivitas guru di sekolah. (8) Mendukung guru yang ingin melakukan penelitian. (8) Ikut berperan dalam menentukan kebijakan ketika pembagian jam mengajar guru. Berbagai usaha dan kegiatan kepala sekolah dalam meningkatkan profesionalisme guru secara berkelanjutan tersebut dapat ditunjukkan dalam gambar histogram sebagai berikut.

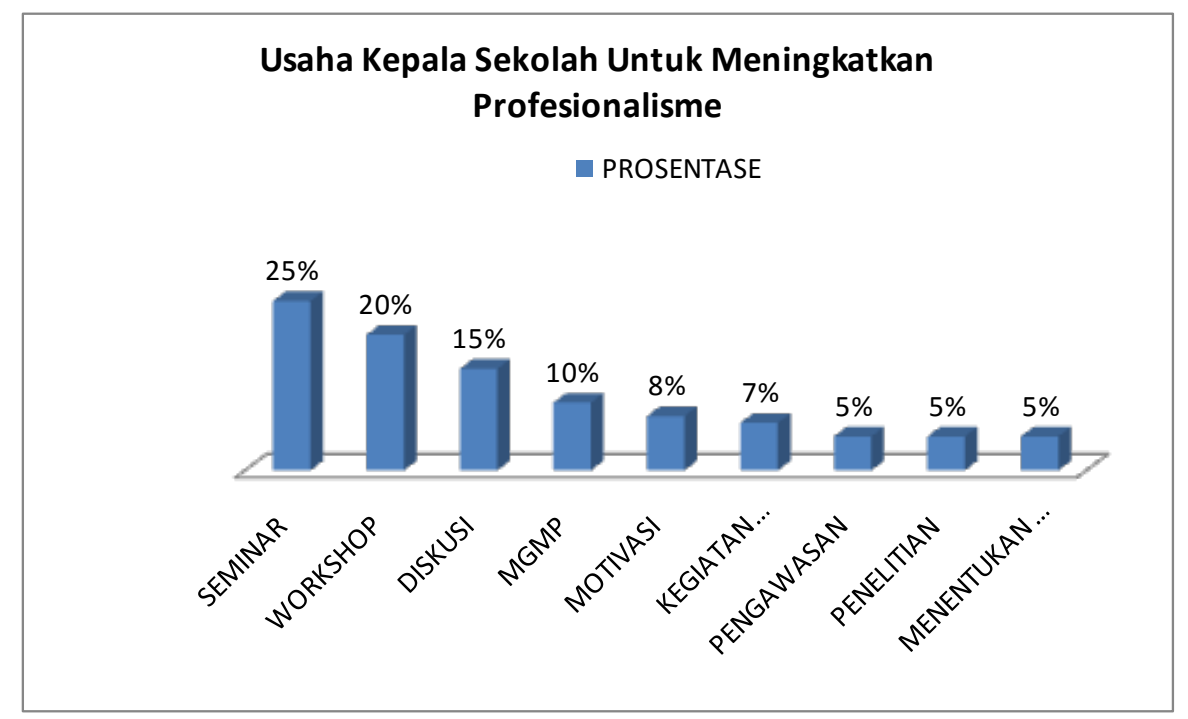

\section{Histogram 3. Usaha Kepala Sekolah Meningkatkan Profesionalisme Guru}

\section{c. Dari Perspektif Majelis Dikdasmen}

Realitas dilapanganmenggambarkan jika pihak Majlis Pendidikan Dasar dan Menengah Muhammadiyah Sukoharjo cenderung mengawasi, memberikan dorongan, dan motivasi kepada aktivitas guru bersertifikasi dalam pengembangan kompetensi. Bisa dikatakan sistem yang sedang terjadi adalah buttom up. Hal itu ditandai dengan segala ide yang muncul dari sekolah masing-masing sehingga Majlis Dikdasmen memberikan dukungan setelah sekolah melakukan action.

Kecilnya peran dan fungi untuk pemberdayaan guru oleh Majlis Dikdasmen Muhammadiyah di Sukoharjo dan mungkin juga di daerahdaerah lain tampaknya dipengaruhi oleh berbagai faktor. Kepengurusan Majlis Dikdasmen sebagian besar dipegang oleh guru atau guru yang sudah purna.

\begin{abstract}
Sebagai perguruan swasta yang tumbuh dan berkembang dari bawah serta memiliki visi sosial keagamaan, yakni dakwah amar makruf nahi munkar maka untuk mewujudkan manajemen sekolah yang profesional sering kesulitan. Hampir sebagian besar sekolah-sekolah Muhammadiyah dalam mengelola keuangan sekolah harus benar-benar menerapkan prinsip-prinsip efisiensi dan efektifitas yang ketat. Karena itu tidak aneh apabila pihak Majlis Dikdasmen sering kesulitan dalam hal pendanaan bila akan membuat gebrakan dan berbagai kegiatan yang diinginkan.
\end{abstract}

\section{Pemetaan dan Kemampuan Guru Dalam Penulisan Karya Ilmiah}

Karya ilmiah adalah hasil pemikiran seorang ilmuwan yang ingin mengembangkan ilmu pengetahuan, teknologi, dan seni. Kegiatan ilmiah diperoleh melalui kepustakaan, kumpulan pengalaman, 
penelitian, dan pengetahuan orang lain sebelumnya. Wawancara kepada Drs. BS, M.Pd (5 Juni 2015), terkait konsep karya ilmiah, mengatakan "Pengusaan konsep penelitian menjadi hambatan saya dalam PTK. Terkadang ketika membuat, tapi bingung ini sudah benar atau belum. Akhirnya berhenti tidak jadi membuat". Menurut Bapak SS, S.Pd guru Sejarah: "Sebenarnya pembelajaran sejarah ada banyak problem. Misalnya motivasi siswa, cara penyampaian metode yang efektif, lantas sumber pembelajaran yang relevan. Itu bisa menjadi tema penelitian tindakan kelas. Hanya konsep PTK tidak terlalu saya kuasai. Agak bingung membuat proposal yang benar dan sistematikanya. Sebenarnya sudah diberikan contoh, tapi karena ilmunya beda jadi tetap merasa kesulitan".

Informasi juga didapat Bapak ES, S.Pd selaku guru PPKn pada tanggal 8 Juni 2015, yang mengatakan "Membuat penelitian mungkin jadi salah satu kelemahan saya, karena dulu saat kuliah tidak menempuh jalur yang skripsi”. Kemudian menurut Drs. W.: "Kesulitan dalam membuat PTK secara umum ada pada pengembangan konsep penelitiannya. Mulai dari menentukan judul yang pas, rumusan masalah, dan teori yang digunakan. Lantas metodenya bagaimana, itu juga jadi hambatan. Seandainya tidak ada yang membimbing, pasti saya kesulitan.

Keterangan yang didapat dari guru SMK Muhammadiyah 1 dan 2 Sukoharjo, dikroscek dengan informasi dari guru SMA Muhammadiyah 1, guru SMAMuhammadiyah 3, dan SMK Muhammadiyah Watukelir yang kesemuanya menyimpulkan masih adanya kendala dalam pemahaman konsep karya ilmiah. Pengalaman guru membuat karya ilmiah, sebagian besar dilakukan pada saat Pendidikan Latihan Profesi Guru (PLPG). Guru merasa kesulitan ketika sudah masuk pada sistematika baku dan metodologi penelitian.

Pemahaman guru-guru bersertifikasi pendidik mengenai konsep karya ilmiah dapat ditunjukkan bahwa yang termasuk kategori paham 15\%, kurang paham 55\%, dan kategori tidak paham 30\%. Kondisi tersebut di atas sejalan dengan hasil penelitian Bambang Sumardjoko (2012) bahwa kendala guru untuk menulis karya tulis ilmiah adalah sebagai berikut. (1) Minat Membaca Rendah. (2) Guru kurang informasi mengenai kegiatan pengembangan terbaru, dan (3) Salah Persepsi. Guru yang kurang informasi akan karya tulis ilmiah menjadikan guru salah persepsi mengenai menulis karya tulis ilmiah.

Selain hal di atas penyebab rendahnya pemahaman terhadap karya ilmiah adalah faktor internal dari guru yang bersangkutan. Faktor internal adalah pengaruh yang datang dari dalam diri seseorang. Motivasi rendah merupakan salah satu faktor penghambat internal yang antara lain terdiri dari sikap para guru yang belum memiliki kebiasaan membaca buku, belum memiliki kemampuan berbahasa yang baik dan belum adanya motivasi untuk menulis. Faktor malas mencoba, minat dan motivasi menulis dapat dilihat dari mau tidaknya mencoba menulis. Malas untuk mencoba merupakan salah satu faktor yang menghambat guru untuk mulai menulis.

\section{Kebutuhan Pengembangan Kepro- fesionalan Guru Berkelanjutan}

Berdasarkan hasil analisis dokumen dan wawancara secara mendalam terhadap guru-guru SMA/MA/SMK Muhammadiyah Sukoharjo dapat dijelaskan bahwa para guru sudah berusaha mengembangkan keprofesionalannya dengan berbagai cara yakni dengan model pengembangan "Individual Guided Staff Development" (Pengembangan Guru yang Dipadu secara Individual). Para guru dapat menilai kebutuhan belajar mereka dan mampu belajar aktif serta mengarahkan diri sendiri. Para guru harus dimotivasi saat menyeleksi tujuan belajar berdasar penilaian personil dari kebutuhan mereka.

Pengembangan profesionalisme secara mandiri yang telah dilakukan guru-guru Muhammadiyah Sukoharjo sesuai dengan 
panduan kegiatan PKB. Kegiatan PKB untuk pengembangan diri dilakukan di dalam sekolah secara mandiri dan dikelompokkan menjadi tiga, yakni (1) dilakukan guru secara mandiri, (2) dilakukan oleh guru bekerja sama dengan guru lain dalam satu sekolah, dan (3) dilakukan melalui jaringan.

Berdasarkan hasil wawancara, pencatatan arsip, dan observasi terdapat beberapa permasalahan muncul terkait pengembangan keprofesionalan guru berkelanjutan. Permasalahan yang kemudian menjadi kendala tersebut adalah masalah waktu, pendanaan, usia, sarana prasarana sekolah, motivasi, kebijakan pimpinan, dan akses jaringan internet. Karena itu, yang dibutuhkan adalah (1) adanya langkah dari pemangku kebijakan untuk menyederhanakan segala hal terkait aktivitas administratif pembelajaran atau pun evaluasi di sekolah. (2) Adanya dukungan dana dari Majelis Dikdasmen dan dari pihak sponsor lain dalam hal membuka jalan bagi aktivitas guru. Majelis Dikdasmen tidak hanya buttom up namun up to down. (3) Adanya perubahan kebijakan dari pimpinan Majelis Dikdasmen agar syarat kenaikan pangkat lebih selektif sehingga menyangkut ranah paedagogik, profesional, kepribadian, dan sosial. (4) Adanya dukungan akses jaringan internet. (5) Adanya dukungan dari lembaga perguruan tinggi dalam penyelenggaraan workshop/ seminar/ lokakarya/ dan kegiatan lainnya. (6) Adanya dukungan beasiswa untuk studi lanjut.

Berdasarkan analisis di atas maka dikembangkan model PKB secara terpadu, yakni dengan melibatkan persyarikatan, LPTK, dan Stakeholder yang mendasarkan pada kebutuhan guru di dalam PKB. Dari hasil analisis penelitian pendahuluan ditemukan komponen yang paling lemah, yakni pemahaman dan kemampuan guru dalam membuat karya ilmiah. Karena itu dikembangan model pengembangan profesi guru berkelanjutan berbasis konstruktivis kolaboratif untuk meningkatkan soft skills transferable skills dalam penulisan artikel ilmiah bagi guru-guru di sekolah menengah Muhammadiyah.

\section{Draft Pengembangan Model}

Berdasarkan studi pendahuluan di atas maka model pengembangan yang dikembangkan didasarkan atas kebutuhan guru dalam menyusun artikel ilmiah untuk pengembangan profesionalismenya. Model dikembangkan secara konstruktif artinya didasari oleh permasalahan yang ditemukan guru sendiri, sementara tim peneliti memberi penguatan dan pendampingan dalam penyusunan artikel ilmiah. Kolaboratif artinya para guru akan berkolaborasi dengan kelompoknya (satu sekolah sama/bidang studi sama), untuk menghasilkan karya ilmiah. Usaha menemukan solusi pemecahan masalah (konstruktif) dan secara kolaboratif menyusun artikel ilmiah, merupakan dasar untuk mengembangkan kemampuan menulis secara lebih mudah dan bermakna karena didasari oleh masalah yang ditemukan guru sendiri. Melalui model ini akan menumbuhkan kepercayaan diri dan motivasi guru untuk menyusun karya ilmiah yang lain.

Langkah-langkah pengembangan model adalah sebagai berikut. (1) Analisis kebutuhan guru dalam menulis karya ilmiah. (2) Menyusun draf model pengembangan profesional guru berbasis konstruktifkolaboratif. (3) Focus group discusion untuk memantapkan model, dan (4) Penyempurnaan perangkat model. Adapun komponenkomponen penting pendukung penyusunan model pengembangan profesionalisme guru berkelanjutan dalam penulisan artikel ilmiah adalah sebagai berikut. (1) Partisipasi seluruh elemen pemangku kepentingan (stakeholder). (2) Majlis Dikdasmen Muhammadiyah yang merupakan komponen kunci menentukan pelaksanaan model. (3) Sekolah yang menyediakan sarana dan prasarana bagi guru. (4) Guru yang merupakan komponen kunci terlaksananya model, dan (5) LPTK (Tim dari FKIP) Universitas Muhammadiyah Surakarta sebagai pendamping dan pengembang. Model pengembangan profesionalisme 
guru berkelanjutan berbasis konstruktivis kolaboratif untuk meningkatkan soft skillstransferable skills dalam penulisan artikel ilmiah bagi guru-guru bersertifikasi pendidik di sekolah menengah Muhammadiyah Sukoharjo dibuat dalam bentuk bagan sebagai berikut.

Bagan Model Pengembangan Profesi Guru Berkelanjutan

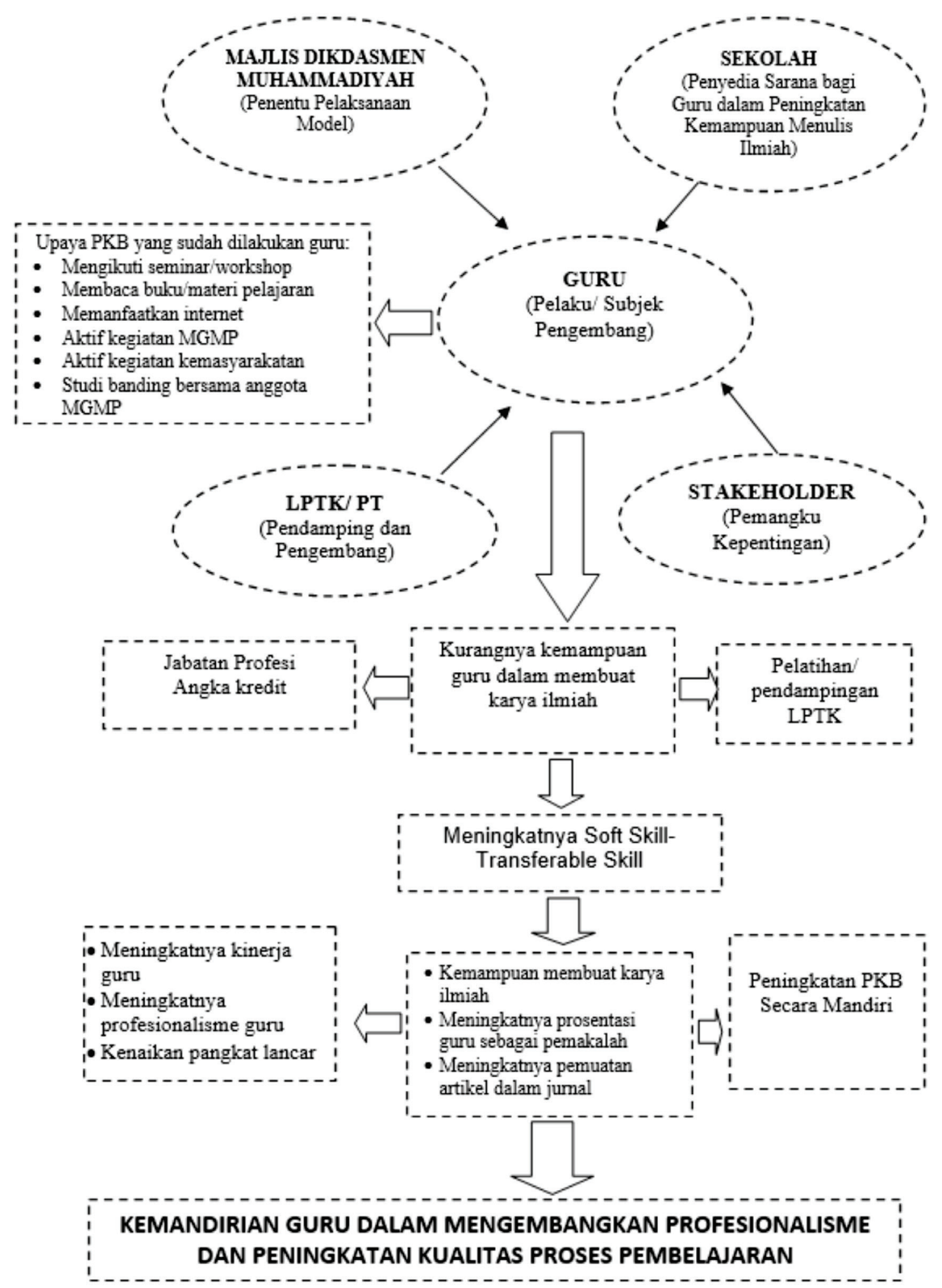




\section{Simpulan}

Pertama, guru-guru SMA/MA/ SMK Muhammadiyah di Sukoharjo yang bersertifikasi pendidik telah melakukan berbagai kegiatan untuk mengembangkan kompetensinya. Pengembangan dilakukan oleh guru secara mandiri dengan mengikuti workshop, seminar, membeli buku teks pelajaran terbaru, mengikuti kegiatan MGMP, serta berdiskusi dengan rekan guru bidang studi. Kedua, dalam kemampuan menulis karya ilmiah guru-guru bersertifikasi pendidik belum sepenuhnya memiliki pemahaman konsep karya ilmiah. Pengalaman guru membuat karya ilmiah sebagian besar dilakukan pada saat PLPG. Pemahaman guru mengenai konsep karya ilmiah secara umum terkendala pada sistematika baku penelitian. Ketiga, untuk memenuhi kebutuhan pengembangan keprofesian guru berkelanjutan maka guru-guru bersertifikasi pendidik masih menemui kendala. Berbagai kendala itu antara lain adalah masalah waktu, dana, usia, sarana prasarana sekolah, motivasi, kebijakan pimpinan, dan akses jaringan internet. Karena itu yang dibutuhkan adalah adanya langkah dari pemangku kebijakan untuk menyederhanakan segala hal terkait aktivitas administratif pembelajaran atau pun evaluasi di sekolah, adanya dukungan dana dari Majelis Dikdasmen dan dari pihak sponsor lain, usulan agar Majelis Dikdasmen tidak hanya buttom up namun up to down, adanya dukungan akses jaringan internet, adanya dukungan dari lembaga perguruan tinggi dalam penyelenggaraan workshop/ seminar/ lokakarya/ dan kegiatan lainnya, serta dukungan beasiswa untuk studi lanjut. Keempat, bentuk awal model pengembangan keprofesian guru berkelanjutan berbasis konstruktivis kolaboratif untuk meningkatkan soft skills transferable skills guru dalam penulisan artikel ilmiah bersifat terpadu. Model pengembangandidasariolehkebutuhan guru dalam menyusun artikel ilmiah yang dikembangkan oleh guru sendiri, sementara tim memberi penguatan dan pendampingan dalam penyusunan artikel ilmiah.

Selanjutnya kepada seluruh elemen pemangku kepentingan, termasuk Majlis Dikdasmen PDM Sukoharjo, Sekolah, Guru, dan LPTK UMS hendaknya lebih meningkatkan partisipasinya dalam mewujudkan pengembangan keprofesionalan secara berkelanjutan bagi guru-guru bersertifikat pendidik khususnya di lingkungan perguruan Muhammadiyah Sukoharjo.

\section{Daftar Pustaka}

Ayhan, S.C. 2011. "Why Turkish Student Prefer to Attentin Vocational Schools." Istambul Turkey. http://www.europeanjounalofscientificrescarch.com.

Barkley, F Elizabeth. 2007. Collaborative Learning Techniques. Jossey-Bass. A Wiley Imprint.

Charlotte Hua Liu and Robert Matthews. 2005. 'Vygotsky's philosophy: Constructivism and its criticisms examined'. International Education Journal. 6 (3): 386-399.

Gordon, Howard R. D. \& Richard Yocke. 1999. "Relationship Between Personality Characteristics and Observable Teaching Effectiveness of Selected Beginning Career and Technical Education Teachers". DLA Ejournal Home. Volume 16, Number 1. Marshall University.

Kemendikbud, 2012. Tentang Kebijakan Pengembangan Profesi Guru

Myers, I. B., \& McCaulley, M.H. 1985. Manual: A Guide to the Development and Use of the Myers-Briggs Type Indicator. Palo Alto, CA: Consulting Psychologists Press.

Payong, Marselus R. 2011. Sertifikasi Profesi Guru; Konsep Dasar, Problematika, dan Implementasinya. Jakarta: PT Indeks Permata Puri Media. 
Sa’ud, Udin Syaefudin. 2009. Pengembangan Profesi Guru. Bandung: Alfabeta.

Sahlberg. 2007. Secondary education in OECD countries. Brasilia. Brazil. www.european training foundation.co

Sumardjoko, B. 2013. "Model Penguatan Guru Bersertifikasi melalui Pemaknaan Profesionalisme pada Guru-guru SMA Negeri di Sukoharjo Jawa Tengah". Laporan Penelitian. Surakarta: LPPM UMS.

Yunanto, Eris. 2007. "Evaluasi Program bimbingan teknis Penulisan karya Ilmiah Pengembangan Profesi Guru Sekolah Menengah di Propinsi Jawa Tengah". Tesis. Semarang: Unnes. 